\title{
Comparative evaluation of seven commercial tests for detection of heterophile antibody in infectious mononucleosis
}

\author{
MARTIN SKULNICK, FIMLS, DONALD E LOW, MD, ANDREW E SIMOR, MD, MOHAN PATEL, BSC,
}

PAULINE GEORGE, BSC, ROBERT CHUA, FIMLS

\begin{abstract}
M Skulnick, DE Low, AE Simor, M Patel, P George, R Chua. Comparative evaluation of seven commercial tests for detection of heterophile antibody in infectious mononucleosis. Can J Infect Dis $1991 ; 3(1): 23-26$. Detection of heterophile antibodies in infectious mononucleosis is the most rapid and cost-effective method for confirming the clinical diagnosis of the disease. This study compared seven commercial test kits (the Oxoid Infectious Mononucleosis Kit [Oxoid Ltd], Immunoscan Im-Latex [Baxter Travenol], Mono-Latex [Wampole Laboratories], Monospot and Im Screen Test [Ortho Diagnostics], Immunoscan Im-RBC Test [Baxter Travenol], and Infectious Mononucleosis Test [NCS Diagnostics]) to the Davidsohn differential test. All of the kits were shown to be acceptable for use, with specificities and sensitivities greater than $96.5 \%$ and $95.5 \%$, respectively.
\end{abstract}

Key Words: Epstein-Barr virus, Heterophile antibodies, Infectious mononucleosis

\section{Evaluation comparative de sept tests commerciaux servant à la détection des anticorps hétérophiles dans la mononucléose infectieuse}

RESUME: La détection des anticorps hétérophiles dans la mononucléose infectieuse est la façon la plus rapide et la plus économique de confirmer le diagnostic clinique. La présente étude a comparé sept tests commerciaux (Oxoid Infectious Mononucleosis Kit [Oxoid Ltd], Immunoscan Im-Latex [Baxter Travenol], Mono-Latex [Wampole Laboratories], Monospot et Im Screen Test [Ortho Diagnostics]) au test différentiel de Davidsohn. Tous les tests se sont avérés acceptables, avec des spécificités et sensibilités supérieures à 96,5 et à $95,5 \%$, respectivement.

Department of Microbiology, Mount Sinai Hospital, University of Toronto; and Department of Virology, Ministry of Health Laboratory Services Branch, Toronto, Ontario

Correspondence and reprints: Mr Martin Skulnick, Department of Microbiology. Mount Sinai Hospital, 600 University Avenue, Room 602, Toronto, Ontario M5G 1 X5

Received for publication September 4, 1990. Accepted January 18, 1991 
$\mathrm{I}$ NFECTIOUS MONONUCLEOSIS IS A COMMON AND USUALLY self-limiting disease caused by the Epstein-Barr virus. The disease is most commonly seen in adolescents and young adults. The diagnosis of infectious mononucleosis is usually made on the basis of clinical symptoms (such as pharyngitis, atypical lymphocytosis, rash, fever, lymphadenopathy and splenomegaly) and confirmed by the detection of infectious mononucleosis heterophile antibodies and/or antibodies to Epstein-Barr virus $(1,2)$. However, certain adult patients may not produce infectious mononucleosis heterophile antibodies, and some children with acute infectious mononucleosis have no measurable heterophile antibodies with current rapid methods $(3,4)$. Other heterophile antibodies such as the Forssman and serum sickness antibodies are produced in a variety of diseases such as rheumatoid arthritis, lymphoma and hepatitis, and must be differentiated from the infectious mononucleosis heterophile antibody (5). In response to this concern, Davidsohn (5) developed a confirmatory differential test which removes Forssman and sheep heterophile antibodies by absorption with beef erythrocytes and guinea pig kidney cells.

\section{MATERIALS AND METHODS}

A total of 318 consecutive sera obtained from nonhospitalized adult and adolescent patients seen in family physicians' offices and suspected of having infectious mononucleosis were tested with each of the commercial kits and compared to the results of the Davidsohn differential test (6). All testing was done in a blinded manner and comparative results were unknown until tabulation of all data was complete.

All sera with discrepant test kit results compared to with the Davidsohn differential test were repeated with the test kit or kits. In addition, specific Epstein-Barr serology using immunofluorescent techniques was performed. These tests were viral capsid antigen IgG (Granbio Inc, California), viral capsid antigen IgM (Gull Laboratories, Utah), early antigen IgG and Epstein-Barr nuclear antigen IgM. Acute infection was defined as the presence of either viral capsid antigen IgM antibodies or antibody to early antigen (7). The two latter tests were performed at the Ministry of Health Laboratories using fluorescent antibody technique.

The kits tested in this study were a cross-section of those available on the market. Three were latex agglutination products (Oxoid Infectious Mononucleosis Kit [Oxoid Ltd, United Kingdom], Immunoscan ImLatex [Baxter Travenol Diagnostics, California] and Mono-Latex [Wampole Laboratories, New Jersey]), and four were red cell agglutination products (Monospot and Im Screen Test [Ortho Diagnostic Systems], Immunoscan Im-RBC test [Baxter Travenol Diagnostics, California] and Infectious Mononucleosis Test [NCS Diagnostics Corp, New York]). The latex agglutination kits all used latex polystyrene beads sensitized with purified bovine red blood cell heterophile antigen. This glycoprotein has been shown to be specific for the infectious mononucleosis heterophile antibody and, therefore, removed the need for procedures to absorb Forssman or serum sickness antibodies as with the monospot kit $(8,9)$. The other four kits all used fresh or modified horse red blood cells.

\section{RESULTS}

Of the 318 sera tested, 89 (28\%) were positive for heterophile antibodies using the Davidsohn differential test. A comparison of the test kit results is shown in Table 1. The results show that all kits had acceptable sensitivities and specificities greater than 95.5\% and $96.5 \%$, respectively.

The sera giving discordant results are shown in Table 2. The majority of sera were discordant against two or fewer kits. However, patient sera 153, 156, 200 and 259 gave discordant results against four test kits each. One serum, 213, positive for the Davidsohn test with a titre of 1:40, was negative against all test kits. However, the viral capsid antigen IgM test was less than 1:10 and the viral capsid antigen IgG and Epstein-Barr nuclear antigen were positive at greater than or equal to $1: 640$ and greater than or equal to $1: 40$, respectively. These results indicate that the Davidsohn test with this

TABLE 1

Heterophile antibody results for seven test kits compared with the Davidsohn differential test

\begin{tabular}{|c|c|c|c|c|c|}
\hline \multirow{2}{*}{$\begin{array}{l}\text { Commercial kit } \\
\text { Latex reagents }\end{array}$} & \multirow[t]{2}{*}{ Antigen } & \multicolumn{2}{|c|}{$\begin{array}{l}\text { No. of samples positive } \\
\text { ( } \% \text { sensitivity)* }\end{array}$} & \multicolumn{2}{|c|}{$\begin{array}{c}\text { No. of samples negative } \\
(\% \text { specificity })^{\dagger}\end{array}$} \\
\hline & & & & & \\
\hline Oxoid & Bovine glycoprotein ${ }^{\ddagger}$ & 86 & $(96.6)$ & 228 & $(99.6)$ \\
\hline Immunoscan & Bovine glycoprotein & 87 & $(97.8)$ & 226 & $(98.7)$ \\
\hline Monolatex & Bovine glycoprotein & 85 & (95.5) & 225 & $(98.3)$ \\
\hline \multicolumn{6}{|l|}{ Red cell reagents } \\
\hline Monospot & Fresh horse red blood cells & 87 & $(96.7)$ & 223 & $(97.4)$ \\
\hline Immunoscan & Modified horse red blood cells & 88 & $(98.9)$ & 221 & $(96.5)$ \\
\hline Ortho IM & Modified horse red blood cells & 86 & $(97.7)$ & 225 & $(98.7)$ \\
\hline NCS & Modified horse red blood cells and latex particles & 85 & $(95.5)$ & 223 & $(97.4)$ \\
\hline
\end{tabular}


TABLE 2

Epstein-Barr virus serology results for discordant test kit results

\begin{tabular}{|c|c|c|c|c|c|c|}
\hline \multirow{2}{*}{$\begin{array}{l}\text { Patient } \\
\text { number }\end{array}$} & \multirow{2}{*}{$\begin{array}{l}\text { Davidsohn test } \\
\text { results }\end{array}$} & \multirow{2}{*}{$\begin{array}{l}\text { Commercial kit with } \\
\text { discordant test results }\end{array}$} & \multicolumn{4}{|c|}{ Antibody titre } \\
\hline & & & VCA IgG & VCA IgM & EA & EBNA \\
\hline 21 & - & IL & $\geq 1: 640$ & $\leq 1: 10$ & $\leq 1: 40$ & $1: 20$ \\
\hline 26 & - & $\mathrm{IM}$ & $\geq 1: 640$ & $\leq 1: 10$ & $\leq 1: 40$ & $\geq 1: 40$ \\
\hline 58 & - & $\mathbb{R}$ & $\geq 1: 640$ & $\leq 1: 10$ & $\leq 1: 40$ & $\geq 1: 40$ \\
\hline 81 & + & IL, IR & $1: 80$ & $\geq 1: 10$ & $\leq 1: 40$ & $\leq 1: 40$ \\
\hline 123 & - & IT & $1: 320$ & $\leq 1: 10$ & $\leq 1: 40$ & $\leq 1: 40$ \\
\hline 156 & - & $\mathbb{I M}, \mathrm{MS}, \mathrm{IT}, \mathbb{I}$ & $\geq 1: 640$ & $\leq 1: 10$ & $\leq 1: 40$ & $\geq 1: 40$ \\
\hline 171 & - & OX.MS & $1: 40$ & $1: 10$ & $\leq 1: 40$ & $\leq 1: 10$ \\
\hline 173 & - & MS, ML & $1: 320$ & NS & NS & $\geq 1: 40$ \\
\hline 200 & + & $O X, I M, I T, M L$ & $1: 320$ & $\leq 1 ; 10$ & $\leq 1: 40$ & $\geq 1: 40$ \\
\hline 201 & - & $\mathbb{I R}$ & $1: 60$ & $\leq 1: 10$ & $\leq 1: 40$ & $\geq 1: 40$ \\
\hline 275 & + & IM, IT, IR & $\geq 1: 640$ & $\leq 1: 10$ & $\leq 1: 40$ & $\leq 1: 10$ \\
\hline 280 & - & $\mathrm{ML}$ & $1: 640$ & $\leq 1: 10$ & $\leq 1: 40$ & $1: 20$ \\
\hline
\end{tabular}

EA Early antigen; EBNA Epstein-Barr nuclear antigen; IL Immunoscan-Latex; IM IM Screen Test; IR Immunoscan RBC; IT Infectious Mononucleosis Test (NCS); ML Mono-Latex: MS Monospot; NS Nonspecific; OX Oxoid Infectious Mononucleosis Kit: VCA Viral capsid antigen

specimen was a false positive. In most cases the Epstein-Barr virus serology was in agreement with the 'gold standard'.

Analysis of discrepant results showed that in all but two patients Epstein-Barr serology was consistent with no acute infection. The two other sera showed evidence of acute infection and could, therefore, represent false negative results of the Davidsohn differential test.

\section{DISCUSSION}

There are many commercial test kits available on the market for detection of infectious mononucleosis heterophile antibody. Several authors have compared many of these kits and have shown that there is no significant statistical advantage concerning sensitivity and specificity (10-12). The present results agree with published reports. In the present study, the erythrocytebased kits, although equal in sensitivity to the latex kits, appeared to be less specific. However, the difference was not statistically significant. This result is also comparable to the study by Hoiby et al (11) which showed an increased number of false positives in erythrocyte-based tests. The Ortho monospot test, which is widely used, has been shown to give false positive reactions occasionally with leukemia, rubella, malaria and several other diseases $(13,14)$. In the present study the monospot test demonstrated a specificity comparable to that of other erythrocyte-based tests. However, the monospot had the disadvantage of an absorption step that was not required in any other test.

In general the latex kits were technically simpler to perform and the endpoint agglutination was easier to read. All tests were rapid, ranging from 2 mins for the NCS test to 4 mins for the Immunoscan latex test. The costs for kits are comparable and would vary from institution to institution depending on the volume of tests.

ACKNOWLEDGEMENTS: We thank Ruth Jaeger and the technologists at MDS Laboratories for their technical assistance and Alice Au Yeung for excellent secretarial services.

\section{REFERENCES}

1. Lennette ET. Epstein-Barr virus. In: Lennette EH, Balows A, Hausler WJ Jr, Shadomy HJ, eds. Manual of Clinical Microbiology, 4th edn. Washington, DC: American Society for Microbiology, 1985:728-32.

2. Paul JR, Bunnell WW. The presence of heterophile antibodies in infectious mononucleosis. Am J Med Sci 1932; 183:90-104.

3. Evans AS, Niederman JC, Cenabre LC, West B, Richards BA. A prospective evaluation of heterophile and Epstein-Barr virus-specific IgM antibody tests in clinical and subclinical infectious mononucleosis. Specificity and sensitivity of the tests and persistence of antibody. $\mathrm{J}$ Infect Dis 1975;132:546-53.

4. Fleischer G, Henle W, Henle G, Lennette ET, Biggar RJ. Primary infection with Epstein-Barr virus in infants in the United States: Clinical and serologic observations. $\mathrm{J}$ Infect Dis 1979;139:553-8.

5. Davidsohn I. Serologic diagnosis of infectious mononucleosis. JAMA 1937;108:289-95.

6. National Communicable Disease Center, Altanta, Georgia. The Morphological and Serological Diagnosis of Infectious Mononucleosis. United States Department of Health, Education, and Welfare. 
7. Andiman WA. Antibody responses to Epstein-Barr virus. In: Rose NR, Friedman H, Fahey JL, eds. Manual of Clinical Laboratory Immunology, 3rd edn. Washington, DC: American Society for Microbiology, 1986:509-14.

8. Halpert SP. Anken M, Henle W, Golubjatnikov R. Detection of infectious mononucleosis heterophile antibody by a rapid, standardized enzyme-linked immunosorbent assay procedure. J Clin Microbiol 1982;15:610-6.

9. Levy BA, Lo TM, Caldwell KE, Fletcher MA. Latex test for serodiagnosis of infectious mononucleosis. J Clin Microbiol 1980;11:256-62.

10. Cook L, Midgett J, Willis D, Clinton B, Folds JD. Evaluation of latex based heterophile antibody assay for diagnosis of acute infectious mononucleosis. J Clin Microbiol 1987;25:2391-4.

11. Hoiby EA, Tjade T, Rotterud OJ. Evaluation of ten commercial heterophile antibody tests for infectious mononucleosis. Acta Pathol Microbiol Immunol Scand 1985:93:145-51.

12. Tilton RC, Dias F, Ryan RW. Comparative evaluation of three commercial tests for the detection of heterophile antibody in patients with infectious mononucleosis. J Clin Microbiol 1988;26:275-8.

13. Horwitz CA, Henle W, Heale G, Penn G, Hofman N, Ward PCJ. Persistently falsely positive rapid tests for infectious mononucleosis. Am J Clin Pathol 1979;72:807-11.

14. Reed RE. False-positive monospot tests in malaria. Am J Clin Pathol 1974;61:173-4. 


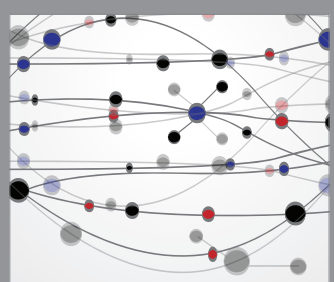

The Scientific World Journal
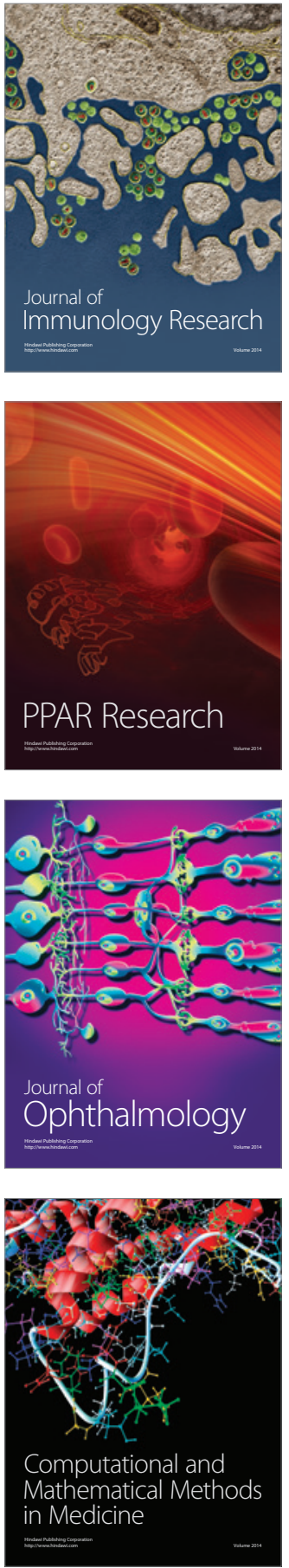

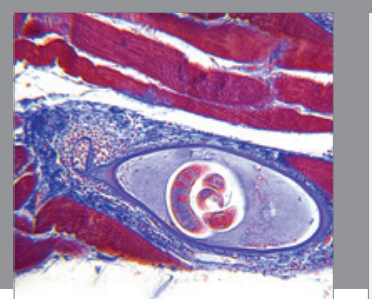

Gastroenterology Research and Practice

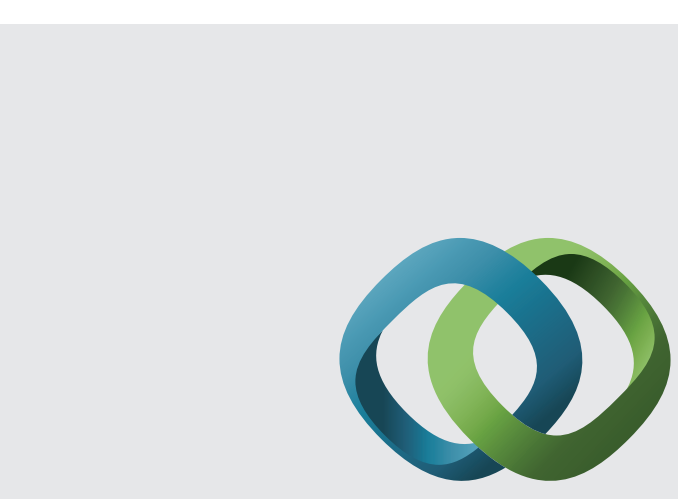

\section{Hindawi}

Submit your manuscripts at

http://www.hindawi.com
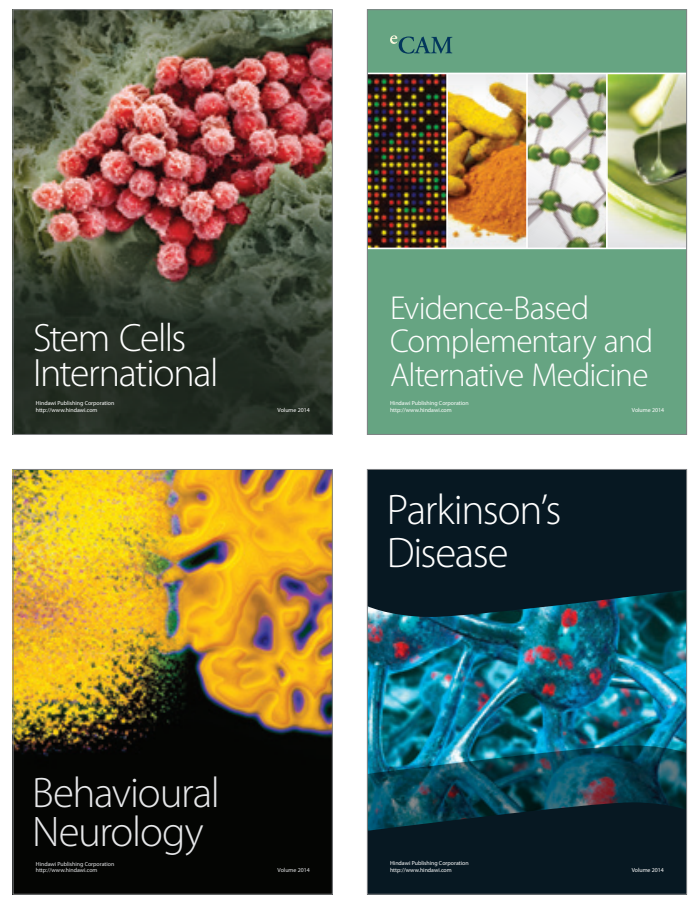
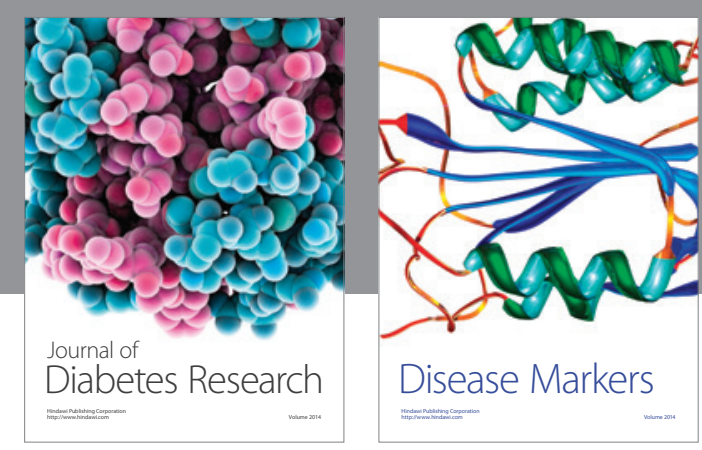

Disease Markers
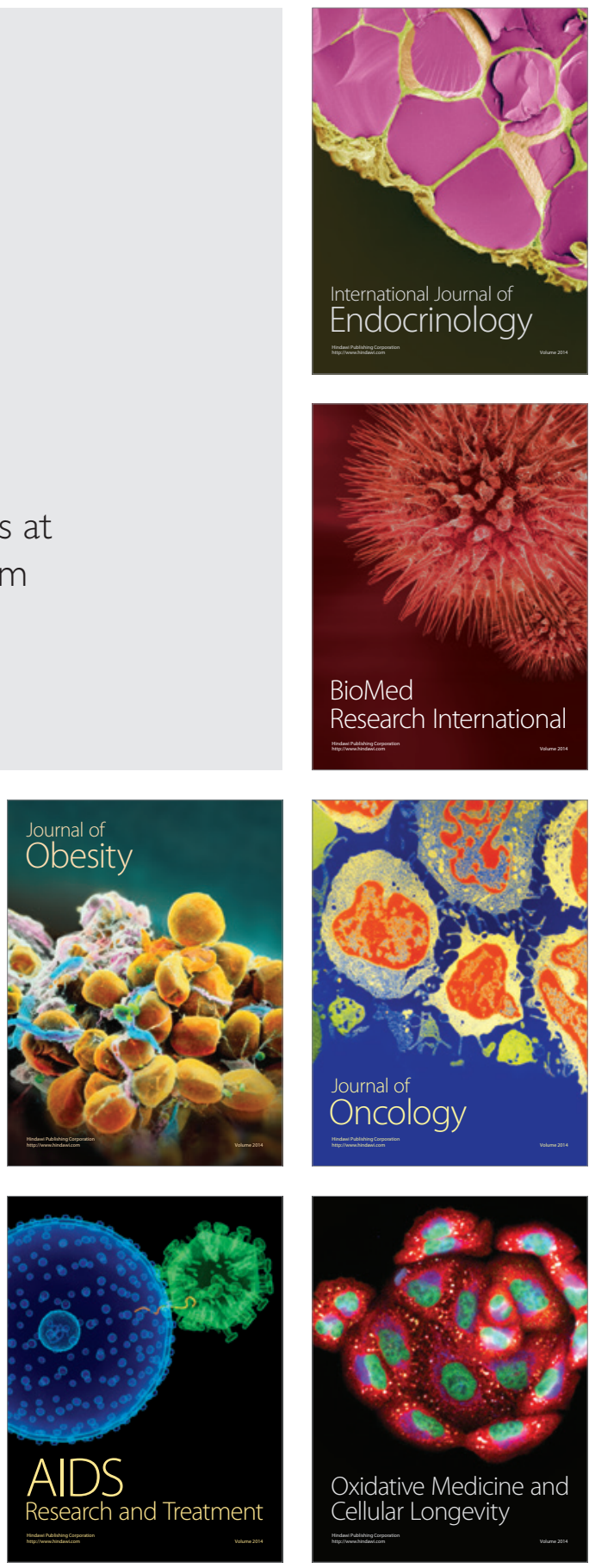